\title{
Article \\ Prevalence, Antibiotic Resistance, Toxin-Typing and Genotyping of Clostridium perfringens in Raw Beef Meats Obtained from Qazvin City, Iran
}

\author{
Samaneh Hassani ${ }^{1}$, Babak Pakbin ${ }^{1,2, * \mathbb{D}}$, Wolfram Manuel Brück ${ }^{2} \mathbb{D}$, Razzagh Mahmoudi ${ }^{1, *}$ \\ and Shaghayegh Mousavi ${ }^{1}$
}

1 Medical Microbiology Research Center, Qazvin University of Medical Sciences, Qazvin 34197-59811, Iran; samanehasani1369@gmail.com (S.H.); sh.mousavi@qums.ac.ir (S.M.)

2 Institute for Life Technologies, University of Applied Sciences Western Switzerland Valais-Wallis, 1950 Sion, Switzerland; wolfram.bruck@hevs.ch

* Correspondence: b.pakbin@ut.ac.ir (B.P.); r.mahmoudi@qums.ac.ir (R.M.)

check for updates

Citation: Hassani, S.; Pakbin, B.; Brück, W.M.; Mahmoudi, R.; Mousavi, S. Prevalence, Antibiotic Resistance, Toxin-Typing and Genotyping of Clostridium perfringens in Raw Beef Meats Obtained from Qazvin City, Iran. Antibiotics 2022, 11, 340. https://doi.org/10.3390/ antibiotics 11030340

Academic Editor: Carlo Corino

Received: 9 February 2022

Accepted: 1 March 2022

Published: 4 March 2022

Publisher's Note: MDPI stays neutral with regard to jurisdictional claims in published maps and institutional affiliations.

Copyright: (c) 2022 by the authors. Licensee MDPI, Basel, Switzerland. This article is an open access article distributed under the terms and conditions of the Creative Commons Attribution (CC BY) license (https:// creativecommons.org/licenses/by/ $4.0 /)$.
Abstract: Background: Clostridium perfringens is one of the highest prevailing spore-forming foodborne pathogens, which is widely distributed and causes severe disease and outbreaks in humans and animals. Raw meat and poultry are the main vehicles of this pathogen. In this study, we investigated the prevalence, antibiotic resistance pattern, toxin-encoding genes and genetic diversity of C. perfringens isolates from raw whole and minced meat samples purchased from local markets in Qazvin city, Iran (the source of beef cattle production was also located in Qazvin city, Iran). Methods: We used conventional culture-based and Kirby-Bauer disk diffusion and conventional and arbitrary primer PCR methods. Results: A total of 18 C. perfringens strains were isolated from 133 raw meat samples (13.53\%). Up to 44.4 and $55.5 \%$ of these isolates were detected in raw minced and whole meat samples, respectively. We found that $72.2,66.6,61.1,37.8$ and $33.3 \%$ of the $C$. perfringens isolates were resistant to ampicillin, tetracycline, amoxicillin, ciprofloxacin and chloramphenicol antibiotics, respectively. Multidrug resistance was found in 38\% of the isolates. Among the four main toxin genes evaluated, the Cpa gene was detected in all isolates, and $61.1 \%$ of the isolates were mostly recognized as type A C. perfringens. High levels of genetic diversity were observed among the isolates, and they were classified into five distinct groups. Conclusions: The isolates from whole meat samples were more resistant to antibiotics. However, toxin genes were more detected in the isolates from minced meat samples. Our findings suggest that contamination of raw meat products with multidrug resistant $C$. perfringens could be regarded as one of the concerning pathogens in these products. Comprehensive monitoring of $C$. perfringens isolates is strongly recommended.

Keywords: Clostridium perfringens; raw meat; antibiotic resistance; toxin gene

\section{Introduction}

Clostridium perfringens is a ubiquitous rod-shaped, Gram-positive, nonmotile anaerobe that grows rapidly and is one of the highest prevailing spore-forming pathogenic bacteria with a worldwide distribution [1]. It has been found in various environments and is present in foods (raw or cooked under anaerobic conditions), sewage, dust and soil. Raw meat and poultry are recognized as the main vehicles of the foodborne diseases caused by $C$. perfringens [2]. It is estimated that C. perfringens, known as one of the most prevalent bacterial pathogens, causes more than one million foodborne illnesses in the United States [1]. However, this pathogen caused several foodborne disease outbreaks in Japan, England, Australia and Wales. These outbreaks were caused mainly by C. perfringens strains and were frequently associated with consuming undercooked or raw contaminated meat and poultry products [3]. 
C. perfringens causes toxico-infectious diseases, such as gastroenteritis and acute diarrhea, in humans, in which their toxins play an important role [4]. This pathogen can produce and release up to 16 various toxins in different combinations. However, four major toxins, namely alpha, beta, epsilon and iota, which are encoded by the $c p a, c p b$, et $x$ and iot genes, respectively, are produced and secreted by $C$. perfringens isolates, causing intestinal diseases [5]. According to the main toxin profile produced by C. perfringens, this pathogen is classified into five distinct toxinotypes consisting of A, B, C, D and E. Most diseases caused by $C$. perfringens strains are mediated by the combination of one or more of these toxins [6]. The alpha toxin is essential for cases of gas gangrene in diseased humans and animals. The $C p b$ gene encodes a toxin responsible for enterotoxemia and necrotizing enteritis, predominantly in the neonates of some animals. The epsilon toxin is responsible for lesions and clinical signs of enterotoxemia, a common neurological disease of goat and sheep caused by $C$. perfringens. The iota toxin mediates the pathogenesis of the intestinal diseases in humans caused by type E C. perfringens [4]. Regarding the fact that the specific toxinotypes of $C$. perfringens strains are associated with specific intestinal and extraintestinal diseases, toxinotyping these pathogens is extremely important [7].

Antibiotics are currently the main treatment of bacterial infectious diseases in humans and animals to decrease the mortality and morbidity associated with disease. Therefore, antibiotic resistance in foodborne bacterial pathogens, and especially those isolated from animal-based foods, have gradually increased all over the world [8]. Irrational and excessive use of various classes of antibiotics for the treatment of infections and the promotion of growth of livestock and farm animals are the main causative factors leading to an increase in antibiotic resistance among foodborne pathogens [9]. Antibiotics such as metronidazole, chloramphenicol, ampicillin, imipenem and tetracycline have been used to decrease the economic losses caused by infectious diseases in the livestock industry and farm animals [10]. Several studies reported that C. perfringens isolated from food samples were mostly resistant to tetracycline, erythromycin and lincomycin antibiotics over the recent decades [11]. When bacterial pathogens are resistant to more than three classes of antibiotics, they are known as multidrug resistant (MDR). Nowadays, one of the major concerns in food safety and public health is the emergence of MDR foodborne pathogens [12].

Genotyping methods have been used to determine the genetic relatedness and diversity among the foodborne pathogens, especially in outbreaks [13]. Several common genotyping assays have been used to type $C$. perfringens isolates from food samples, including multiple-locus variable-number tandem repeat analysis (MLVA), multi-locus sequence typing (MLST), amplified polymorphic DNA (RAPD), pulsed-field gel electrophoresis (PFGE), amplified fragment length polymorphism (AFLP), arbitrary primer PCR-based (AP-PCR) and toxinotyping methods [14,15]. There are limited studies to characterize the antibiotic resistance, presence of toxin genes and genetic relatedness in C. perfringens isolated from raw meat samples [16-19]. Therefore, the purpose of this study was to determine the prevalence rate, antimicrobial susceptibility, toxinotype and genetic diversity in C. perfringens isolates from raw whole and minced meat samples.

\section{Results}

\subsection{Isolation and Identification of C. perfringens in Raw Meat Samples}

In this study, C. perfringens were isolated from a total of 18 out of $133(13.53 \%)$ raw meat samples. The prevalence rate of $C$. perfringens isolated from minced and whole meat samples is shown in Figure 1. All C. perfringens isolates were initially isolated using culturebased methods and then confirmed and identified using biochemical tests. Among all C. perfringens isolates, 8 out of $18(44.44 \%)$ and 10 out of $18(55.55 \%)$ isolates were detected in raw minced and whole meat samples, respectively. The prevalence rate of $C$. perfringens was significantly ( $p<0.05$, chi-square test) higher in raw whole meat than that in the raw minced meat samples. 


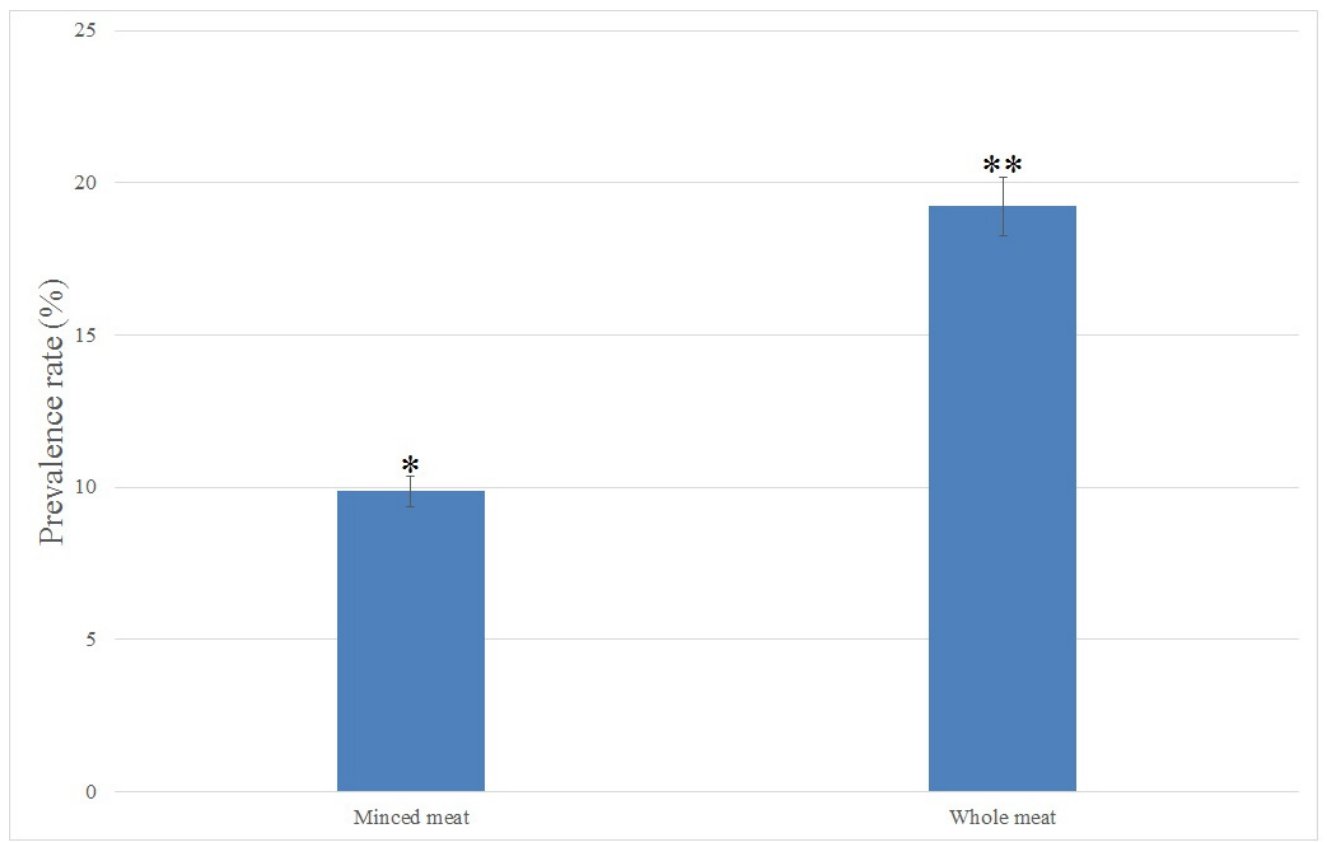

Figure 1. Prevalence rates of $C$. perfringens in the different raw meat samples. ${ }^{*}$ and ${ }^{* *}$ indicate significant differences $(p<0.05$, chi-square test).

\subsection{Antimicrobial Susceptibility Testing of the C. perfringens Isolates}

All eighteen $C$. perfringens isolates were tested for antibiotic resistance against six diverse classes of antibiotics and nine different commercial antibiotics. The results of the antimicrobial susceptibility testing of the isolates are illustrated in Table 1. In total, $13(72.2 \%), 12(66.6 \%), 11(61.1 \%), 7(37.8 \%)$ and $6(33.3 \%)$ out of the 18 C. perfringens isolates from raw meat samples were resistant to ampicillin, tetracycline, amoxicillin, ciprofloxacin and chloramphenicol antibiotics, respectively. The lowest levels of antibiotic resistance were seen against imipenem ( 5 out of $18 ; 27.7 \%$ ), ceftriaxone ( 4 out of $18 ; 22.2 \%$ ), amikacin ( 3 out of $18 ; 16.6 \%$ ) and cefepime ( 3 out of $18 ; 16.6 \%$ ) in the C. perfringens isolates from all raw meat samples. Notably, significantly $(p<0.05)$ higher levels of antibiotic resistance were observed in the $C$. perfringens isolates from the raw whole meat samples than that in the raw minced meat samples. In this study, we found that 7 out of $18(38.8 \%)$ C. perfringens isolates from all raw meat samples were resistant to at least three different classes of antibiotics and were considered to be MDR C. perfringens isolates (Table 2). The frequency of multidrug resistance patterns among the $C$. perfringens isolates were similar $(n=1)$. The group of isolates that was resistant to three classes of antibiotics was the most frequent one $(n=3)$. Notably, diverse patterns of resistance to different antibiotic classes were observed among the C. perfringens isolates (Table 2).

\subsection{Toxin-Encoding Genes in C. perfringens Isolates}

Toxin-encoding genes, including the $c p a, c p b$, cpe, etx and iap genes, were detected and identified in C. perfringens isolated from the raw whole and minced meat samples by a conventional multiplex PCR assay using specific primers. All C. perfringens isolates (18 out of $18 ; 100 \%$ ) harbored the cpa gene encoding the alpha toxin. Five $C$. perfringens isolates $(27.7 \%)$ harbored cpe or $e t x$, two isolates (11.1\%) harbored $c p b$ and only one isolate (5.5\%) harbored the iap toxin-encoding genes (Table 3$)$. Toxin genes were significantly $(p<0.05)$ more detected in the $C$. perfringens isolates from the raw minced meat samples than those from the raw whole meat samples. Moreover, 61.1 and $22.2 \%$ (11 out of 18 ) of C. perfringens isolates were identified as toxinotypes A and D, respectively, in this study (Table 3). 
Table 1. Antibiotic resistance phenotype of C. perfringens isolated from the raw beef meat samples.

\begin{tabular}{llccc}
\hline \multirow{2}{*}{ Antibiotic Class } & Antibiotic Agent & \multicolumn{3}{c}{$\mathbf{n}(\mathbf{\%})$} \\
\cline { 2 - 4 } & & $\begin{array}{c}\text { Whole Meat } \\
\mathbf{( n = 1 0 )}\end{array}$ & $\begin{array}{c}\text { Minced Meat } \\
(\mathbf{n}=\mathbf{8})\end{array}$ & $\begin{array}{c}\text { Total } \\
(\mathbf{n}=\mathbf{1 8})\end{array}$ \\
\hline \multirow{3}{*}{$\beta$-Lactams } & imipenem & $4(40.0)$ & $1(12.5)$ & $5(27.7)$ \\
& amoxicillin & $7(70.0)$ & $4(50.0)$ & $11(61.1)$ \\
& ampicillin & $7(70.0)$ & $6(75.0)$ & $13(72.2)$ \\
Cephalosporins & ceftriaxone & $3(30.0)$ & $0(0.0)$ & $3(16.6)$ \\
\hline Aminoglycosides & amikacin & $4(40.0)$ & $0(0.0)$ & $4(22.2)$ \\
\hline Fluoroquinolones & ciprofloxacin & $2(20.0)$ & $1(12.5)$ & $3(16.6)$ \\
\hline Phenicols & chloramphenicol & $5(50.0)$ & $2(25.0)$ & $7(38.8)$ \\
\hline Tetracyclines & tetracycline & $3(30.0)$ & $3(37.5)$ & $6(33.3)$ \\
\hline
\end{tabular}

Table 2. Patterns of multidrug resistance classes of the C. perfringens isolates from the raw meat samples.

\begin{tabular}{|c|c|c|}
\hline $\begin{array}{l}\text { No. Classes of } \\
\text { Antibiotics }\end{array}$ & $\begin{array}{l}\text { Patterns of Multidrug Resistance } \\
\text { (No. Isolates in Each Pattern) }\end{array}$ & $\begin{array}{l}\text { No. Total Isolates }(\%) \\
(\mathrm{n}=18)\end{array}$ \\
\hline One & $\begin{array}{l}\beta \operatorname{Ls}(n=1) \\
\text { TCs }(n=2)\end{array}$ & $3(16.6)$ \\
\hline Two & $\begin{array}{l}\beta \text { Ls-TCs }(\mathrm{n}=5) \\
\beta \text { Ls-CPs }(\mathrm{n}=1) \\
\beta \text { Ls-PNs }(\mathrm{n}=1) \\
\text { QNs-TCs }(\mathrm{n}=1)\end{array}$ & $8(44.4)$ \\
\hline Three & $\begin{array}{l}\beta L s-T C s-Q N s(n=1) \\
\beta L s-P N s-Q N s(n=1) \\
\beta L s-T C s-C P s(n=1)\end{array}$ & $3(16.6)$ \\
\hline Four & $\begin{array}{l}\beta \text { Ls-PNs-QNs-AGs }(\mathrm{n}=1) \\
\beta \text { Ls-PNs-QNs-TCs }(\mathrm{n}=1)\end{array}$ & $2(11.1)$ \\
\hline Five & $\beta$ Ls-CPs-QNs-TCs-AGs $(\mathrm{n}=1)$ & $1(5.5)$ \\
\hline Six & $\beta$ Ls-CPs-QNs-TCs-AGs-PNs $(\mathrm{n}=1)$ & $1(5.5)$ \\
\hline
\end{tabular}

\subsection{Genotyping and Molecular Toxinotyping of the C. perfringens Isolates}

Genotyping of the $C$. perfringens isolates from the raw meat samples was performed by conventional PCR using arbitrary OPA-3 primers. The method was able to type all isolates (18 out of $18 ; 100 \%)$, which were differentiated into five distinct groups $(\mathrm{O} 1, \mathrm{O} 2, \mathrm{O} 3, \mathrm{O} 4$ and O5), indicating the genetic diversity that exists among the different $C$. perfringens isolates (Figure 2). According to Simpson's index of diversity, the discriminating capability of the PCR method with the OPA-3 primer for the genotyping of the C. perfringens isolates in this study was relatively high $(73.2 \%)$ regarding the $50 \%$ similarity coefficient. The genetic relatedness among the isolates ranged from 50 to $74 \%$, indicating a high level of genetic variation (Figure 2). Any significant differences in banding profiles were considered to differentiate between two OPA-3 typing groups. 
Table 3. Resistance phenotype, toxin genes, toxinotypes and OPA-3 genotypes in C. perfringens isolated from the raw whole and minced meat samples.

\begin{tabular}{|c|c|c|c|c|c|c|}
\hline $\begin{array}{l}\text { No. } \\
\text { Sample }\end{array}$ & Isolate & Source & Resistance Phenotype ${ }^{\text {a }}$ & Toxin Genes & $\begin{array}{l}\text { Toxin } \\
\text { Type }\end{array}$ & $\begin{array}{l}\text { OPA-3 } \\
\text { Group }\end{array}$ \\
\hline 1 & CPQM19-1 & Whole meat & TET and CIP & cpa+ & A & $\mathrm{O} 1$ \\
\hline 2 & CPQM19-2 & Whole meat & $\begin{array}{l}\text { IPM, AMX, AMK, AMP, TET, FEP, } \\
\text { CHL, CIP, and CRO }\end{array}$ & cpa+ & A & $\mathrm{O} 1$ \\
\hline 3 & CPQM19-3 & Whole meat & AMX, TET, and AMP & cpa+cpe+ & Ae & $\mathrm{O} 1$ \\
\hline 4 & CPQM19-4 & Whole meat & CIP, AMX, AMP, and TET & cpa+ & A & $\mathrm{O} 1$ \\
\hline 5 & CPQM19-5 & Whole meat & CRO, FEP, AMX, AMP, and TET & cpa+etx+ & $\mathrm{D}$ & $\mathrm{O} 1$ \\
\hline 6 & CPQM19-6 & Whole meat & $\mathrm{CRO}$ and $\mathrm{AMP}$ & $c p a+$ & A & O1 \\
\hline 7 & CPQM19-7 & Whole meat & FEP and CHL & cpa+ & A & $\mathrm{O} 2$ \\
\hline 8 & CPQM19-8 & Minced meat & TET and AMP & cpa+etx+ & $\mathrm{D}$ & $\mathrm{O} 1$ \\
\hline 9 & CPQM19-9 & Minced meat & AMK, CIP, AMX, AMP, and CHL & cpa+cpe+ & Ae & $\mathrm{O} 2$ \\
\hline 10 & CPQM19-10 & Minced meat & AMP & $c p a+c p e+c p b+$ & $\mathrm{Ce}$ & $\mathrm{O} 3$ \\
\hline 11 & CPQM19-11 & Minced meat & TET & $c p a+c p b+e t x+$ & B & $\mathrm{O} 3$ \\
\hline 12 & CPQM19-12 & Minced meat & $\begin{array}{l}\text { IPM, CIP, AMX, AMP, TET, } \\
\text { and CHL }\end{array}$ & $c p a+e t x+$ & $\mathrm{D}$ & $\mathrm{O} 4$ \\
\hline 13 & CPQM19-13 & Minced meat & TET & $c p a+c p e+$ & $\mathrm{Ae}$ & $\mathrm{O} 3$ \\
\hline 14 & CPQM19-14 & Minced meat & AMX, AMP, and TET & $c p a+i a p+$ & $\mathrm{E}$ & O5 \\
\hline 15 & CPQM19-15 & Whole meat & IPM, AMX, AMP, and TET & $c p a+e t x+$ & $\mathrm{D}$ & $\mathrm{O} 2$ \\
\hline 16 & CPQM19-16 & Whole meat & $\begin{array}{l}\text { IPM, AMX, AMK, AMP, TET, CIP, } \\
\text { and CRO }\end{array}$ & $c p a+$ & A & $\mathrm{O} 1$ \\
\hline 17 & CPQM19-17 & Whole meat & IPM, CIP, AMX, and CHL & cpa+ & A & $\mathrm{O} 2$ \\
\hline 18 & CPQM19-18 & Minced meat & FEP, AMX, and TET & cpa+cpe+ & $\mathrm{Ae}$ & $\mathrm{O} 2$ \\
\hline
\end{tabular}

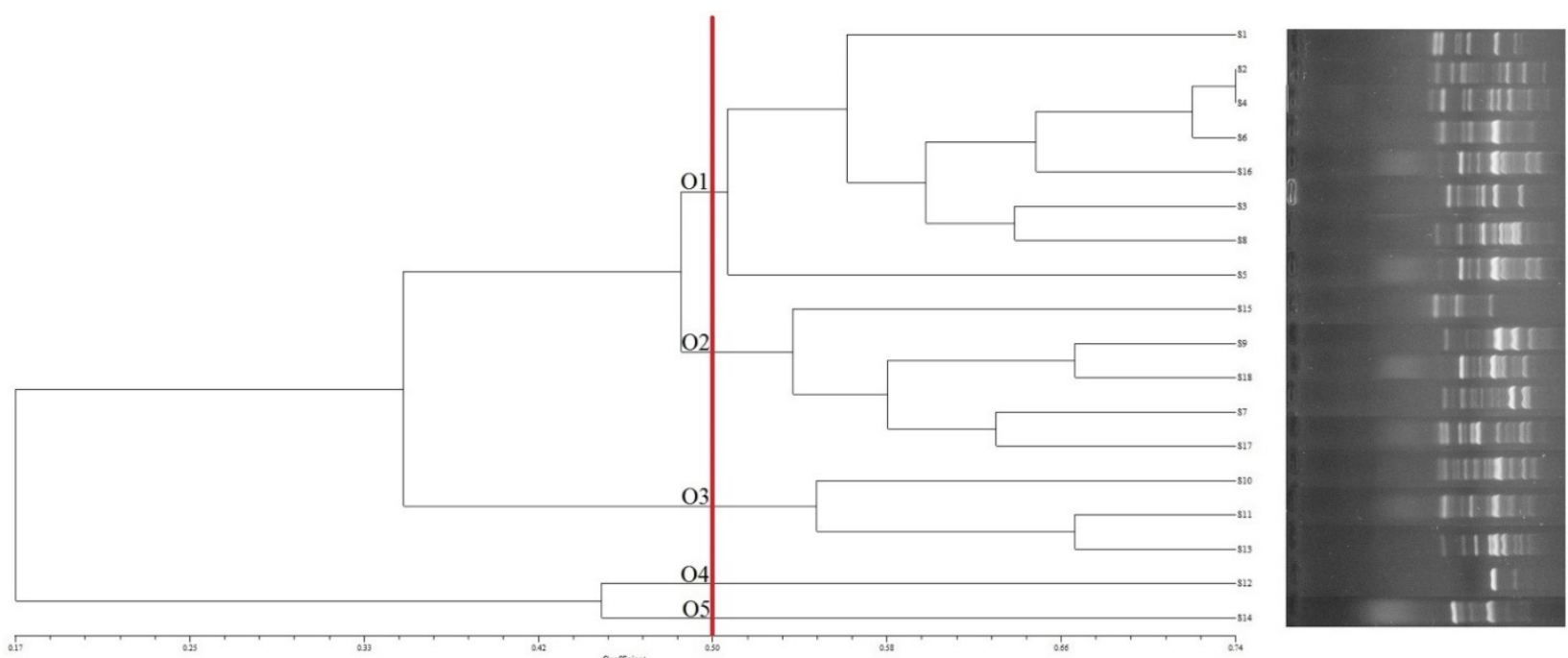

Figure 2. UPGMA dendrogram of the $C$. perfringens isolates from the raw meat samples based on the OPA-3 PCR analysis.

Based on the source of the isolates, the resistance phenotype, presence of toxin genes, toxinotypes and genotypes in the isolates are shown in Table 3 . The isolates from the raw minced meat samples were included in all genotyping clusters (O1-O5). The isolates from 
the whole meat samples were only detected in the groups $\mathrm{O} 1$ and $\mathrm{O} 2$, indicating that there are higher levels of genetic diversity among the C. perfringens isolates from the minced meat samples. Clusters $\mathrm{O} 4$ and $\mathrm{O} 5$ contained one isolate each. The greatest number of isolates ( 8 out of $18 ; 44.4 \%$ ) were included in cluster O1. Three types of toxins, including the $\mathrm{A}, \mathrm{Ae}$ and $\mathrm{D}$ toxinotypes, were detected in the isolates from the whole meat samples. Five different types of toxins consisting of the Ae, B, Ce, D and E toxinotypes were seen in the $C$. perfringens isolates from the minced meat samples. The $\mathrm{A}$ and $\mathrm{E}$ toxinotypes were only detected in the isolates from the raw whole and minced meat samples, respectively. Moreover, higher levels of toxinotype diversity and variation in the presence of different toxin genes were seen among the isolates from the raw minced meat samples. In addition, higher levels of antibiotic resistance were observed in the C. perfringens isolates from the raw whole meat samples (Table 3).

\section{Discussion}

C. perfringens is the main cause of human gas gangrene and some major important foodborne diseases in humans [20]. This pathogen also has the ability to form spores protecting the bacterial cell against stress conditions, such as exposure to heat and oxygen, allowing $C$. perfringens to survive in varied environments and through thermal processes, including sterilization and cooking, allowing it to reach the high levels that are needed to cause food poisoning [21]. Due to these properties, C. perfringens has been regarded as an important foodborne pathogen. C. perfringens is widely distributed in the gastrointestinal tracts of humans, animals and soil as a ubiquitous pathogen [4]. C. perfringens endospores can be transmitted via food, water and food commodities to humans, causing foodborne diseases. Foods, especially raw meat products, are the main transmission vehicle of this pathogen to humans [22]. Poor hygiene and sanitation and insufficient thermal processing conditions during food production and distribution contribute to the increase in the prevalence rates of $C$. perfringens in meat products and also lead to an increase in the incidence of foodborne diseases caused by this pathogen [23]. Limited studies investigated the antimicrobial susceptibility and toxinotype profiles in C. perfringens isolated from food samples. Therefore, we conducted this research to determine the toxinotypes, antibiotic resistance and genotypic relationship among these properties in C. perfringens isolated from raw meat samples, as they are the main foods contaminated with this foodborne pathogen.

Few studies are currently available regarding the prevalence of $C$. perfringens in foods as well as raw meat products [24]. In this study, the total prevalence rate of $C$. perfringens was significantly higher than that reported from Côte d'Ivoire (12.4\%; 49 out of 395 food samples) [25], Kazakhstan (9\%; 18 out of 197 food samples) [26] and Nigeria (13.18\%; 29 out of 220 food samples) [16] and lower than that reported from Argentina (24.46\%; 126 out of 515 food meat samples) [27], Japan (71.0\%; 143 out of 200 total different meat products) [28], Turkey (92\%; 92 out of 100 ground beef and sheep meat samples) [29], China (23.1 and $15.1 \%$; 130 and 38 out of 562 broiler chicken and 252 retail chicken samples, respectively) [30] and Korea (19\%; 38 out of 200 chicken, beef and pork meat samples) [31]. These differences may be because of strong variations in hygienic and sanitary conditions of handling, processing and distribution of the products [32]. However, the results of the C. perfringens prevalence rate in the raw meat samples showed that, regarding the lower prevalence rate, there is still a high risk with respect to contamination with this pathogen in raw meat products due to poor hygiene and low levels of sanitation practices that have been used during raw meat processing and distribution [19,31]. The results in this study also showed that the prevalence rate of $C$. perfringens was significantly $(p<0.05$, chi-square test) higher in raw whole meat samples than that in minced meat samples. Notably, depending on the type of meat used, minced meat is more likely to be contaminated than whole meats due to the extra handling throughout the grinding process and the release of meat juice that allows spoilage bacteria and foodborne pathogens to multiply [33]. However, only a very limited number of studies investigated differences in the prevalence of $C$. perfringens between minced and whole meat samples. Previously, in Argentina, Stagnitta et al. [27] 
reported that minced meat was more contaminated with $C$. perfringens than other raw meat products. In another study that was conducted recently by Yibar et al. [34], C. perfringens was isolated in higher levels in raw minced meat and beef meatball than that in other raw meat products. The results obtained in this study suggested that higher prevalence rate of $C$. perfringens may not necessarily imply substantial C. perfringens contamination in raw meat products in Iran. Instead, using accurate and efficient isolation and identification assays might have contributed to a significantly higher recovery of $C$. pefringens from raw meat samples.

Antibiotic resistance genes could be transmitted horizontally between various foodborne bacterial pathogens via conjugative plasmids [35]. These genes also could be transferred from various environments and animal-based foods to the commensal microbiota and opportunistic pathogens in human and animals through food chains [36]. There were also few studies on the antimicrobial susceptibility evaluation of $C$. perfringens isolates from food sources [37]. A study in Korea showed high levels of antibiotic resistance in C. perfringens isolated from pork, duck, chicken and beef meat samples and they found that 100,97, $97,93,83,73,20,10,7,7$ and $3 \%$ of the isolates were resistant against ampicillin, penicillin, bacitracin, tetracycline, erythromycin, oxytetracycline, gentamicin, trimethoprim, amikacin and streptomycin antibiotics, respectively [15]. Another study, which was performed in Korea, reported C. perfringens strains isolated from pork, chicken and beef meat samples were resistant to tetracycline (38 out of 38 isolates; 100\%), imipenem (27 out of 38 isolates; $71 \%$ ), chloramphenicol (26 out of 38 isolates; $68.4 \%$ ) and metronidazole (13 out of 38 isolates; $34.2 \%$ ) [31]. Another study, which was conducted recently by Anju et al. [38], reported that $44,40,40$ and $26.6 \%$ of $C$. perfringens isolated from livestock and poultries were resistant to gentamicin, erythromycin, bacitracin and tetracycline antibiotics, respectively. Several previous studies showed that C. perfringens isolated from food samples were mostly susceptible to ciprofloxacin and chloramphenicol, which corresponds to our findings. Higher resistance to tetracycline of $C$. perfringens isolates that were reported in other studies is due to the excessive use of this antibiotic and incorrect veterinary advice [39]. We also found that $C$. perfringens isolates from raw whole meat samples were more resistant than isolates from minced meat samples. Recently, resistance to various classes of antibiotics have been developed worldwide in C. perfringens isolated from food and clinical samples [24,38]. The prevalence rate of MDR C. perfringens isolated from raw meat samples was significantly lower than that of MDR isolates from raw animal-based food samples reported in Korea (78.9\%) [31] and China (90.1\%) [30]. Lower antibiotic resistance and prevalence rates of MDR C. perfringens isolated from raw meat samples is probably due to the rational, effective and appropriate usage of antibiotics in livestock production and treatment of diseases animals in farms $[11,37,38]$.

C. perfringens is categorized into five distinct toxinotypes (A-E) based on the production of four major toxins, including the alpha, beta, epsilon and iota toxins, which are encoded by the cpa, cpe, et $x$ and iot genes, respectively $[5,23,31]$. However, different strains of this pathogen can produce and release up to 16 various toxins in different combinations, such as the perfringolysin $\mathrm{O}$ and beta2 toxins [6]. There are also limited studies on detection of the four main toxin-encoding genes and the determination of toxinotypes in C. perfringens isolates collected from food samples. In Turkey, Erol et al. [40] reported that all C. perfringens isolates from turkey meat samples carried the cpa gene, all of them were recognized as toxinotype A, and none of the other toxin genes were detected. A few years later, Guran and Oksuztepe [41] detected the cpe and cpb2 toxin genes in C. perfringens isolates from turkey meat samples for the first time in Turkey. Another study, which was performed in Iran by Afshari et al. [42], reported 70.9 (22 out of 31) and 29\% (9 out of 31) of C. perfringens isolates from broiler meat samples as types $C$ and $A$, respectively. A study that has recently been conducted in China by Zhang et al. [30] showed type A as the most predominant toxinotype in 168 C. perfringens isolates from chicken meat samples. Another study, which was recently implemented in Korea by Jang et al. [31], revealed that the cpa gene was predominantly detected in all 38 C. perfringens isolates collected from retail meat samples. Consequently, 
all isolates were recognized as type A. Our findings correspond with the previous studies performed in Turkey [29], Korea [31] and China [30] and are in disagreement with the results of the study that was previously conducted in Iran [42]. Detection of the cpa gene in almost all $C$. perfringens isolates from different types of raw meat samples indicates that it might be a specific universal gene in these isolates [43]. This is the first of type $\mathrm{E}$ C. perfringens in raw meat samples, as none of the other studies have isolated such a strain. It is worthwhile to note that the cpa gene is located on the chromosome. Other toxin genes, including $c p b$, etx and iot, are plasmid borne, except for the cpe gene, which may be located on either plasmids or the chromosome [6]. The acquisition or loss of these plasmids must explain the toxinotype changes seen in the isolates [39]. The C. perfringens isolates in this study might have lost their plasmids, as mobile genetic elements containing the toxin genes except cpa, which explains why the other toxin genes were not detected in the isolates. The genes encoding the toxins of $C$. perfringens are of great importance from a global public health perspective and are associated with gastrointestinal disorders in humans, such as watery and acute diarrhea, abdominal cramping and necrotizing enteritis $[4,5]$.

To determine the genetic diversity and clonal relatedness among the pathogenic bacterial isolates from food sources, several DNA fingerprinting methods based on arbitrary primers methods have been widely used [44]. It has been shown that these methods are highly efficient to discriminate different genotypes and identify genetic clusters of pathogens that are associated with foodborne disease outbreaks [45]. In the present study, we used a conventional PCR method using an arbitrary OPA-3 primer for the genotyping of C. perfringens isolates collected from raw whole and minced meat samples. In this study, we differentiated the $C$. perfringens isolates into five distinct groups (O1-O5) and observed an appropriate discriminatory index of 0.73 . In contrast with our findings, Chukwu et al. [19] found $44.7 \%$ of the $C$. perfringens isolates were typeable using PCR-based genotyping with arbitrary OPA-3 primers. Llanco et al. [46] found all (100\%) of the C. perfringens isolates typeable, which is in agreement with our findings. Due to fact the raw meat samples were non-outbreak related and that random and different types of samples were analyzed [47], a relatively wide genetic diversity among the C. perfringens isolates was expected in this study. However, the results of the genotyping in our study could not precisely establish a definite and significant relationship between the origin and source of the isolates in the dendrogram [19]. However, we found a relationship between the antibiotic resistance, toxinotype, OPA-3 genotype profiles and the type of raw meat sample (whole and minced) among the C. perfringens isolates in this study. We also found that antibiotic resistance, the presence of toxin genes and the genotyping patterns between the isolates from whole and minced meat samples were significantly different, and the cause of this difference was not clear and has not been investigated yet. However, we believe that the main limitation of this study is the small sample size. Consequently, more studies are highly recommended to investigate the reasons for the differences between the molecular and phenotypic characteristics of $C$. perfringens isolated from raw whole and minced meat samples.

\section{Materials and Methods}

\subsection{Sample Collection}

A total of 133 raw meat samples, including 81 minced and 52 whole meat samples, taken from the shank and tenderloin parts of slaughtered beef cattle, were purchased and collected from 46 different local markets located in several areas throughout Qazvin city, Iran, between March and July 2019. All raw meat samples were collected in separated and UV sterilized plastic bags and containers and transported immediately in cool boxes containing ice packs to the laboratory of food microbiology of Qazvin University of Medical Science for further microbiological analysis. 


\subsection{C. perfringens Isolation}

C. perfringens were isolated and identified in raw minced and whole meat samples according to the method that has been previously described by Chukwu et al. [16]. All raw meat samples were inoculated into cooked meat broth (HiMedia, Mumbai, India) and incubated anaerobically at $37^{\circ} \mathrm{C}$ for $24 \mathrm{~h}$ for enrichment. Next, $100 \mu \mathrm{L}$ of bacterial growth was aliquoted to the plates containing tryptose sulphite cycloserine agar (TSC, HiMedia, Mumbai, India), Columbia blood agar (CBA, HiMedia, Mumbai, India) and Clostridium perfringens agar (CPA, HiMedia, Mumbai, India) and incubated at $37^{\circ} \mathrm{C}$ for $48 \mathrm{~h}$ in an anaerobic atmosphere generated using Gas Pack A (Merck, Darmstadt, Germany) in an anaerobic jar (MahAzma, Terhan, Iran) according to the manufacturer's instructions. Presumptive colonies of $C$. perfringens including black colonies on CPA or TSC and the typical colonies with a double zone of beta-hemolysis on CBA were selected for further biochemical and morphological identification. All confirmed C. perfringens isolates were stocked in bovine heart infusion broth (BHI, HiMedia, Mumbai, India) containing 20\% $(v / v)$ glycerol, incubated at $37^{\circ} \mathrm{C}$ in an anaerobic atmosphere for $24 \mathrm{~h}$ and stored at $-80{ }^{\circ} \mathrm{C}$ for subsequent analysis. C. perfringens ATCC 13124 was used as the positive control in this study. This control strain was activated in BHI broth (HiMedia, Mumbai, India) and incubated anaerobically at $37^{\circ} \mathrm{C}$ for $24 \mathrm{~h}$.

\subsection{Antimicrobial Susceptibility Testing}

The antimicrobial susceptibility of the $C$. perfringens isolates was evaluated using the Kirby-Bauer disk diffusion method based on interpretive criteria and the standards established and developed previously by the Clinical and Laboratory Standards Institute [17]. In this study, nine commercial antibiotic disks (Oxoid, Basingstoke, UK) were used, including $30 \mu \mathrm{g}$ of cefepime (FEP), $10 \mu \mathrm{g}$ of ampicillin (AMP),25 $\mathrm{g}$ of amoxicillin (AMX), $10 \mu \mathrm{g}$ of imipenem (IPM), $30 \mu \mathrm{g}$ of amikacin (AMK), $30 \mu \mathrm{g}$ of chloramphenicol (CHL), $30 \mu \mathrm{g}$ of tetracycline (TET), $30 \mu \mathrm{g}$ of ceftriaxone and $5 \mu \mathrm{g}$ of ciprofloxacin. The results of the antibiotic susceptibility testing were recorded and described according to the CLSI standards [18]. The Escherichia coli ATCC 25922, Klebsiella pneumoniae ATCC 700603 and Staphylococcus aureus ATCC 25923 strains were used as the positive and negative controls in this study [48].

\subsection{DNA Extraction}

All isolates were grown anaerobically in BHI broth (HiMedia, Mumbai, India) overnight at $37^{\circ} \mathrm{C}$. Next, $1 \mathrm{~mL}$ of the bacterial suspension was mixed with the same volume of phosphate buffered saline (PBS, HiMedia, Mumbai, India) and centrifuged at $6000 \times g$ for 5 min. After the removal of supernatant, the microbial sediment was subjected to DNA extraction using a SinaClon bacterial Gram-positive DNA extraction kit (SinaClon Co., Tehran, Iran) according to the manufacturer's instruction. The quality and quantity of the extracted genomes were evaluated spectrophotometrically using a NanoDrop model ND-1000 (ThermoFisher Scientific, Waltham, MA, USA). Prior to the PCR reactions, the concentrations of all extracted DNA were adjusted to $50 \mu \mathrm{g} / \mathrm{mL}$ with PBS.

\subsection{Identification of Toxin Genes}

Toxin-encoding genes, including the $c p a, c p e, c p b$, etx and iap genes, in the C. perfringens isolates were detected and identified using a conventional multiplex PCR assay. Specific primers, which have previously been described by Chukwu et al. [16], were used in this study (Table 4). A $20 \mu \mathrm{L}$ PCR reaction mixture contained $10 \mu \mathrm{L}$ of the PCR Master Mix kit (Ampliqon, Odense, Denmark), $0.5 \mu \mathrm{L}$ of each primer $(1 \mu \mathrm{M} / \mu \mathrm{L}), 1 \mu \mathrm{L}$ of the DNA template $(50 \mu \mathrm{g} / \mathrm{mL})$ and sterilized nuclease free water up to the final reaction volume. The PCR reaction was performed using a Biorad T-100 thermocycler (Biorad, Hercules, CA, USA) that was programmed to: initial denaturation step at $95{ }^{\circ} \mathrm{C}$ for $5 \mathrm{~min}$, followed by 30 cycles comprising $95^{\circ} \mathrm{C}$ for $45 \mathrm{~s}, 56^{\circ} \mathrm{C}$ for $45 \mathrm{~s}$ and $72{ }^{\circ} \mathrm{C}$ for $2 \mathrm{~min}$, and a final extension step at $72{ }^{\circ} \mathrm{C}$ for $6 \mathrm{~min}$. The PCR products were characterized using electrophoresis in $1.5 \%$ 
$w / v$ agarose gel containing DNA safe stain (Invitrogen, Carlsbad, CA, USA) at $100 \mathrm{~V}$ for $45 \mathrm{~min}$ and photographed using the Novin-Pars Gel Documentation system (NovinPars Co., Tehran, Iran). The C. perfringens ATCC 13124 strain (cpa gene positive) was used as the control.

Table 4. Primer sequences used in this study for the genotyping and detection of C. perfringens toxin-encoding genes.

\begin{tabular}{llll}
\hline Primer & Sequence $\left(\mathbf{5}^{\prime}-\mathbf{3}^{\prime}\right)$ & Annealing Temperature $\left({ }^{\circ} \mathbf{C}\right)$ & Amplicon $(\mathbf{b p})$ \\
\hline Cpa & $\begin{array}{l}\text { AGTCTACGCTTGGGATGGAA } \\
\text { TTTCCTGGGTTGTCCATTTC }\end{array}$ & 56 & 900 \\
\hline Cpe & $\begin{array}{l}\text { GGGGAACCCTCAGTAGTTTCA } \\
\text { ACCAGCTGGATTTGAGTTTAATG }\end{array}$ & 56 & 506 \\
\hline Cpb & $\begin{array}{l}\text { TCCTTTCTTGAGGGAGGATAAA } \\
\text { TGAACCTCCTATTTTGTATCCCA }\end{array}$ & 56 & 611 \\
\hline Etx & $\begin{array}{l}\text { TGGGAACTTCGATACAAGCA } \\
\text { TTAACTCATCTCCCATAACTGCAC }\end{array}$ & 56 & 396 \\
\hline Iap & $\begin{array}{l}\text { AAACGCATTAAAGCTCACACC } \\
\text { CTGCATAACCTGGAATGGCT }\end{array}$ & 56 & 293 \\
\hline OPA-3 & AGTCAGCCAC & 42 & - \\
\hline
\end{tabular}

\subsection{Determination of Genetic Diversity}

The genetic diversity of the $C$. perfringens isolates was measured by the PCR method using the arbitrary primer OPA-3 (Table 4), which has previously been described by Chukwu et al. [19]. Amplifications were performed in $25 \mu \mathrm{L}$ reaction volumes containing $10 \mu \mathrm{L}$ of the PCR Master Mix kit (Ampliqon, Odense, Denmark), $1 \mu \mathrm{L}$ of the primer $(5 \mu \mathrm{M} / \mu \mathrm{L}), 2 \mu \mathrm{L}$ of the DNA template $(50 \mu \mathrm{g} / \mathrm{mL})$ and deionized nuclease free water up to the final reaction volume. The PCR was performed as follows: initial denaturation cycle at $95{ }^{\circ} \mathrm{C}$ for $5 \mathrm{~min} ; 35$ cycles of $95^{\circ} \mathrm{C}$ for $5 \mathrm{~min}, 42{ }^{\circ} \mathrm{C}$ for $1 \mathrm{~min}$ and $72{ }^{\circ} \mathrm{C}$ for $2 \mathrm{~min}$; and a final extension step at $72{ }^{\circ} \mathrm{C}$ for $10 \mathrm{~min}$. The amplified products were characterized using $1.2 \%$ $w / v$ agarose gel electrophoresis at $80 \mathrm{~V}$ for $2 \mathrm{~h}$. The gels were stained with DNA safe stain (Invitrogen, Carlsbad, CA, USA). The gels were visualized, and the OPA-3 patterns were recorded by an electrophoresis gel documentation system (NovinPars Co., Tehran, Iran). The OPA-3 markers were analyzed using PyElph software version 1.4 [20]. The dendrogram was generated based on the UPGMA clustering (Dice coefficient) of the OPA-3 profiles using NTSYS-pc software version 2.1 [21]. The OPA-3 patterns of the C. perfringens isolates with a similarity index higher than 0.5 were considered to be closely related OPA-3 pattern groups. Simpson's index of genetic diversity was used to evaluate the discriminating power of the OPA-3 PCR assay in genotyping local isolates of $C$. perfringens as described by Chukwu et al. [19].

\subsection{Statistical Analysis}

A chi-square test was used to measure the significant differences $(p<0.05)$ between the prevalence rates by SPSS software version 21.0.1 (IBM Corp., Armonk, NY, USA). All experiments and measurements were carried out in triplicate.

\section{Conclusions}

In conclusion, we determined the prevalence rate, antimicrobial susceptibility, toxin type and genetic relatedness of $C$. perfringens isolates from raw whole and minced beef meat samples collected from local stores in Qazvin city, Iran from March to July in 2019. In this study, we isolated C. perfringens from raw meat samples. The isolates showed a high level of resistance to ampicillin, tetracycline, amoxicillin, ciprofloxacin and chloramphenicol antibiotics. The cpa gene, encoding alpha toxin, was identified in all isolates. High levels of 
clonal diversity were observed among the isolates. Moreover, higher levels of antibiotic resistance were observed among the isolates from raw whole meat samples. Toxin genes were more detected in the isolates from raw minced meat samples. Notably, the sample size in this study was comparably small. Therefore, implementing frequent and comprehensive monitoring, molecular characterization and antimicrobial resistance testing of C. perfringens isolates collected from raw meat samples is highly recommended.

Author Contributions: Conceptualization, S.H. and B.P.; methodology, B.P.; software, W.M.B.; validation, R.M., B.P. and S.M.; formal analysis, B.P.; investigation, R.M.; resources, S.M.; data curation, B.P.; writing — original draft preparation, B.P.; writing-review and editing, W.M.B.; visualization, R.M.; supervision, R.M.; project administration, S.H.; funding acquisition, S.H. All authors have read and agreed to the published version of the manuscript.

Funding: This research received no external funding.

Institutional Review Board Statement: Not applicable.

Informed Consent Statement: Not applicable.

Data Availability Statement: We confirm that all data included in this study are available within the article.

Acknowledgments: We thank our colleagues from the Medical Microbiology Research Center, Qazvin University of Medical Science, who assisted us in this research.

Conflicts of Interest: The authors declare no conflict of interest.

\section{References}

1. McClane, B.A.; Robertson, S.L.; Li, J. Clostridium perfringens. In Food Microbiology: Fundamentals and Frontiers; Wiley Publishing: Hoboken, NJ, USA, 2012; pp. 465-489.

2. Hailegebreal, G. A review on clostridium perfringens food poisoning. Glob. Res. J. Public Health Epidemiol. $2017,4,104-109$.

3. Carey, J.; Cole, J.; Venkata, S.L.G.; Hoyt, H.; Mingle, L.; Nicholas, D.; Musser, K.A.; Wolfgang, W.J. Determination of Genomic Epidemiology of Historical Clostridium perfringens Outbreaks in New York State by Use of Two Web-Based Platforms: National Center for Biotechnology Information Pathogen Detection and FDA GalaxyTrakr. J. Clin. Microbiol. 2021, 59, e02200-20. [CrossRef] [PubMed]

4. Navarro, M.A.; McClane, B.A.; Uzal, F.A. Mechanisms of Action and Cell Death Associated with Clostridium Perfringens Toxins. Toxins 2018, 10, 212. [CrossRef] [PubMed]

5. Duracova, M.; Klimentova, J.; Fucikova, A.M.; Zidkova, L.; Sheshko, V.; Rehulkova, H.; Dresler, J.; Krocova, Z. Targeted Mass Spectrometry Analysis of Clostridium Perfringens Toxins. Toxins 2019, 11, 177. [CrossRef] [PubMed]

6. Rood, J.I.; Adams, V.; Lacey, J.; Lyras, D.; McClane, B.A.; Melville, S.B.; Moore, R.J.; Popoff, M.R.; Sarker, M.R.; Songer, J.G.; et al. Expansion of the Clostridium perfringens toxin-based typing scheme. Anaerobe 2018, 53, 5-10. [CrossRef] [PubMed]

7. Uzal, F.A.; Freedman, J.C.; Shrestha, A.; Theoret, J.R.; Garcia, J.; Awad, M.M.; Adams, V.; Moore, R.J.; Rood, J.I.; McClane, B.A Towards an understanding of the role of Clostridium perfringens toxins in human and animal disease. Future Microbiol. 2014, 9 , 361-377. [CrossRef]

8. Aslam, B.; Wang, W.; Arshad, M.I.; Khurshid, M.; Muzammil, S.; Rasool, M.H.; Nisar, M.A.; Alvi, R.F.; Aslam, M.A.; Qamar, M.U.; et al. Antibiotic resistance: A rundown of a global crisis. Infect. Drug Resist. 2018, 11, 1645-1658. [CrossRef]

9. Sifri, Z.; Chokshi, A.; Cennimo, D.; Horng, H. Global contributors to antibiotic resistance. J. Glob. Infect. Dis. 2019, 11, 36-42. [CrossRef]

10. Bengtsson-Palme, J.; Kristiansson, E.; Larsson, D.J. Environmental factors influencing the development and spread of antibiotic resistance. FEMS Microbiol. Rev. 2018, 42, fux053. [CrossRef]

11. Adams, V.; Han, X.; Lyras, D.; Rood, J.I. Antibiotic resistance plasmids and mobile genetic elements of Clostridium perfringens. Plasmid 2018, 99, 32-39. [CrossRef]

12. Bin Zaman, S.; Hussain, M.A.; Nye, R.; Mehta, V.; Mamun, K.T.; Hossain, N. A Review on Antibiotic Resistance: Alarm Bells are Ringing. Cureus 2017, 9, e1403. [CrossRef] [PubMed]

13. Spurgin, L.G.; Richardson, D.S. How pathogens drive genetic diversity: MHC, mechanisms and misunderstandings. Proc. R. Soc. B Biol. Sci. 2010, 277, 979-988. [CrossRef] [PubMed]

14. Feng, Y.; Fan, X.; Zhu, L.; Yang, X.; Liu, Y.; Gao, S.; Jin, X.; Liu, D.; Ding, J.; Guo, Y.; et al. Phylogenetic and genomic analysis reveals high genomic openness and genetic diversity of Clostridium perfringens. Microb. Genom. 2020, 6, e000441. [CrossRef] [PubMed]

15. Xiu, L.; Liu, Y.; Wu, W.; Chen, S.; Zhong, Z.; Wang, H. Prevalence and multilocus sequence typing of Clostridium perfringens isolated from 4 duck farms in Shandong province, China. Poult. Sci. 2020, 99, 5105-5117. [CrossRef] 
16. Chukwu, E.; Nwaokorie, F.; Coker, A.O.; Avila-Campos, M.J.; Solís, R.L.; Llanco, L.; Ogunsola, F.T. Detection of toxigenic Clostridium perfringens and Clostridium botulinum from food sold in Lagos, Nigeria. Anaerobe 2016, 42, 176-181. [CrossRef]

17. Kahlmeter, G.; Giske, C.G.; Kirn, T.J.; Sharp, S.E. Point-Counterpoint: Differences between the European Committee on Antimicrobial Susceptibility Testing and Clinical and Laboratory Standards Institute Recommendations for Reporting Antimicrobial Susceptibility Results. J. Clin. Microbiol. 2019, 57, e01129-19. [CrossRef]

18. Humphries, R.; Ambler, J.; Mitchell, S.; Castanheira, M.; Dingle, T.; Hindler, J.; Koeth, L.; Sei, K.; on behalf of the CLSI Methods Development and Standardization Working Group of the Subcommittee on Antimicrobial Susceptibility Testing. CLSI Methods Development and Standardization Working Group best practices for evaluation of antimicrobial susceptibility tests. J. Clin. Microbiol. 2018, 56, e01934-17. [CrossRef]

19. Chukwu, E.E.; Nwaokorie, F.O.; Coker, A.O.; Avila-Campos, M.J.; Ogunsola, F.T. Genetic variation among Clostridium perfringens isolated from food and faecal specimens in Lagos. Microb. Pathog. 2017, 111, 232-237. [CrossRef]

20. Pavel, A.B.; Vasile, C.I. PyElph-A software tool for gel images analysis and phylogenetics. BMC Bioinform. 2012, 13, 9. [CrossRef]

21. NTSYS-PC. Numerical Taxonomy and Multivariate Analyses System: NTSYS-PC 2.2. Available online: http://www. appliedbiostat.com/ntsyspc/ntsyspc.html (accessed on 25 November 2021).

22. Ghoneim, N.; Hamza, D. Epidemiological studies on Clostridium perfringens food poisoning in retail foods. Rev. Sci. Tech. 2017, 36, 1025-1032. [CrossRef]

23. Lee, C.-A.; Labbé, R. Distribution of Enterotoxin- and Epsilon-Positive Clostridium perfringens Spores in U.S. Retail Spices. J. Food Prot. 2018, 81, 394-399. [CrossRef] [PubMed]

24. Li, J.; Zhou, Y.; Yang, D.; Zhang, S.; Sun, Z.; Wang, Y.; Wang, S.; Wu, C. Prevalence and antimicrobial susceptibility of Clostridium perfringens in chickens and pigs from Beijing and Shanxi, China. Vet. Microbiol. 2020, 252, 108932. [CrossRef] [PubMed]

25. Kouassi, K.A.; Dadie, A.T.; N'Guessan, K.F.; Dje, K.M.; Loukou, Y.G. Clostridium perfringens and Clostridium difficile in cooked beef sold in Côte d'Ivoire and their antimicrobial susceptibility. Anaerobe 2014, 28, 90-94. [CrossRef]

26. Maikanov, B.; Mustafina, R.; Auteleyeva, L.; Wiśniewski, J.; Anusz, K.; Grenda, T.; Kwiatek, K.; Goldsztejn, M.; Grabczak, M. Clostridium botulinum and Clostridium perfringens Occurrence in Kazakh Honey Samples. Toxins 2019, 11, 472. [CrossRef]

27. Stagnitta, P.V.; Micalizzi, B.; de Guzmán, A.M.a.S. Prevalence of enterotoxigenic Clostridium perfringens in meats in San Luis, Argentina. Anaerobe 2002, 8, 253-258. [CrossRef]

28. Miki, Y.; Miyamoto, K.; Kaneko-Hirano, I.; Fujiuchi, K.; Akimoto, S. Prevalence and Characterization of Enterotoxin GeneCarrying Clostridium perfringens Isolates from Retail Meat Products in Japan. Appl. Environ. Microbiol. 2008, 74, 5366-5372. [CrossRef]

29. Aras, Z.; Hadimli, H.H. Detection and molecular typing of Clostridium perfringens isolates from beef, chicken and turkey meats. Anaerobe 2015, 32, 15-17. [CrossRef] [PubMed]

30. Zhang, T.; Zhang, W.; Ai, D.; Zhang, R.; Lu, Q.; Luo, Q.; Shao, H. Prevalence and characterization of Clostridium perfringens in broiler chickens and retail chicken meat in central China. Anaerobe 2018, 54, 100-103. [CrossRef] [PubMed]

31. Jang, Y.-S.; Kim, D.-H.; Bae, D.; Kim, S.-H.; Kim, H.; Moon, J.-S.; Song, K.-Y.; Chon, J.-W.; Seo, K.-H. Prevalence, toxin-typing, and antimicrobial susceptibility of Clostridium perfringens from retail meats in Seoul, Korea. Anaerobe 2020, 64, 102235. [CrossRef]

32. Choi, Y.; Kang, J.; Lee, Y.; Seo, Y.; Lee, H.; Kim, S.; Lee, J.; Ha, J.; Oh, H.; Kim, Y.; et al. Quantitative microbial risk assessment for Clostridium perfringens foodborne illness following consumption of kimchi in South Korea. Food Sci. Biotechnol. 2020, 29, 1131-1139. [CrossRef]

33. Ziomek, M.; Drozd, Ł.; Gondek, M.; Pyz-Łukasik, R.; Pedonese, F.; Florek, M.; Domaradzki, P.; Skałecki, P. Microbiological Changes in Meat and Minced Meat from Beavers (Castor fiber L.) during Refrigerated and Frozen Storage. Foods 2021, $10,1270$. [CrossRef]

34. Yibar, A.; Cetin, E.; Ata, Z.; Erkose, E.; Tayar, M. Clostridium perfringensContamination in Retail Meat and Meat-Based Products in Bursa, Turkey. Foodborne Pathog. Dis. 2018, 15, 239-245. [CrossRef]

35. Lerminiaux, N.A.; Cameron, A.D.S. Horizontal transfer of antibiotic resistance genes in clinical environments. Can. J. Microbiol. 2019, 65, 34-44. [CrossRef]

36. Martinez, J.L.; Coque, T.M.; Baquero, F. What is a resistance gene? Ranking risk in resistomes. Nat. Rev. Genet. 2014, 13, 116-123. [CrossRef]

37. Walsh, C.; Fanning, S. Antimicrobial resistance in foodborne pathogens-A cause for concern? Curr. Drug Targets 2008, 9, 808-815. [CrossRef]

38. Anju, K.; Karthik, K.; Divya, V.; Mala Priyadharshini, M.L.; Sharma, R.K.; Manoharan, S. Toxinotyping and molecular characterization of antimicrobial resistance in Clostridium perfringens isolated from different sources of livestock and poultry. Anaerobe 2020, 67, 102298. [CrossRef]

39. Park, M.; Rafii, F. The prevalence of plasmid-coded cpe enterotoxin, $\beta 2$ toxin, tpeL toxin, and tetracycline resistance in Clostridium perfringens strains isolated from different sources. Anaerobe 2019, 56, 124-129. [CrossRef]

40. Erol, I.; Goncuoglu, M.; Ayaz, N.; Ormanc1, F.S.B.; Hildebrandt, G. Molecular typing of Clostridium perfringens isolated from turkey meat by multiplex PCR. Lett. Appl. Microbiol. 2008, 47, 31-34. [CrossRef]

41. Guran, H.; Oksuztepe, G. Detection and typing of C lostridium perfringens from retail chicken meat parts. Lett. Appl. Microbiol. 2013, 57, 77-82. [CrossRef] 
42. Afshari, A.; Jamshidi, A.; Razmyar, J.; Rad, M. Genotyping of Clostridium perfringens isolated from broiler meat in northeastern of Iran. Vet. Res. Forum Int. 2015, 6, 279-284.

43. Góra, B.; Gofron, Z.; Grosiak, M.; Aptekorz, M.; Kazek, B.; Kocelak, P.; Radosz-Komoniewska, H.; Chudek, J.; Martirosian, G. Toxin profile of fecal Clostridium perfringens strains isolated from children with autism spectrum disorders. Anaerobe 2018, 51, 73-77. [CrossRef]

44. Miao, J.; Wang, W.; Xu, W.; Su, J.; Li, L.; Li, B.; Zhang, X.; Xu, Z. The fingerprint mapping and genotyping systems application on methicillin-resistant Staphylococcus aureus. Microb. Pathog. 2018, 125, 246-251. [CrossRef]

45. Chen, Q.; Xie, S. Genotypes, Enterotoxin Gene Profiles, and Antimicrobial Resistance of Staphylococcus aureus Associated with Foodborne Outbreaks in Hangzhou, China. Toxins 2019, 11, 307. [CrossRef]

46. Llanco, L.; Nakano, V.; Avila-Campos, M.J. Sialidase Production and Genetic Diversity in Clostridium perfringens Type A Isolated from Chicken with Necrotic Enteritis in Brazil. Curr. Microbiol. 2014, 70, 330-337. [CrossRef]

47. Hu, W.-S.; Kim, H.; Koo, O.K. Molecular genotyping, biofilm formation and antibiotic resistance of enterotoxigenic Clostridium perfringens isolated from meat supplied to school cafeterias in South Korea. Anaerobe 2018, 52, 115-121. [CrossRef]

48. Pakbin, B.; Mahmoudi, R.; Mousavi, S.; Allahyari, S.; Amani, Z.; Peymani, A.; Qajarbeygi, P.; Hoseinabadi, Z. Genotypic and antimicrobial resistance characterizations of Cronobacter sakazakii isolated from powdered milk infant formula: A comparison between domestic and imported products. Food Sci. Nutr. 2020, 8, 6708-6717. [CrossRef] 